\title{
Anti-MüLlerian Hormone (AMH) - Marker of Female Reproductive Ageing and for Assessing Ovarian Function and Ovarian Stimulation Outcome
}

\author{
Juliano Brum Scheffer* \\ Director Scientific of Brazilian Institute of Assisted Reproduction, IBRRA, Brazil
}

Submission: April 03, 2017; Published: April 05, 2017

*Corresponding author: Juliano Brum Scheffer, Brazilian Institute of Assisted Reproduction, IBRRA - Rua Desembargador Jorge Fontana, 408,10 andar, Belvedere, Belo Horizonte, MG, CEP: 30320670, Brazil, Tel: 55-3-32868171; Email: drjulianoscheffer@gmail.com

\section{Opinion}

The fecundity of women begins to decrease after the age of 30 years, primarily as a result of a decrease in the proportion of normal eggs available, which in turn is a consequence of a Continuous process of oocyteatresia. Although all women experience this decrease in fecundity, it is difficult to predict the pace of reproductive decline in an individual woman.

The maximum number of oocytesis 6-7 million, occurring at a gestational age of about 20 weeks in the female fetus. This number decreases to about 1-2 million oocytes at birth, $300,000-500,000$ at puberty, 25,000 at an age of 37 years, and 1000 at an age of 51 years

Women's fecundity decreases gradually, but significantly, beginning after an age of 30 years and then more rapidly in the mid- to late-30s, and is effectively negligible almost a decade before menopause. This age-related decline in fecundity is characterized by a decrease in both eggquality and number, and a population-basedchange in the expression of markers of ovarian activity, such as a gradual increase in circulating FSH and decreases in circulating anti-Mülleri an hormone (AMH) and inhibin B concentrations

To predict ovarian reserve and reproductive potential, several different measures of ovarian reserve have been identified over time, including biochemical measures and ovarian imaging. In recent years, data have emerged to support $\mathrm{AFC}$ and $\mathrm{AMH}$ level as prefer red methods for predicting ovarian reserve Anti-Müllerian hormone, also known as Müllerian inhibiting substance, is a member of the TGF- $\beta$ family most commonly known for its role in the regression of Müllerian ducts during male fetal sex differentiation. In females, $\mathrm{AMH}$ is produced by small an tral and pre-antral follicles, and has been shown to inhibit excess recruitment of primordial follicles through reducing responsiveness to $\mathrm{FSH}$. AMH serum concentration has been shown to be correlated with the ovarian follicular pool, so it is considered to be a marker of ovarian reserve as well as a marker of ovarian follicular activity. Numerous studies have demonstrated that AMH is associated with ovulatory disorders, such as primary ovarian insufficiency, polycysticovary syndrome (PCOS), and ovarian hyperstimulation syndrome AMH levels are correlated with the number of early stage antral follicles The decrease in AMH levels that occurs with increased age may be noted before changes in other age-related variables, suggesting serum AMH levels may be the best marker of ovarian ageing. Determination of functional ovarian reserve as indicated by a woman's AMH level is likely to be helpful in selecting an appropriat estimulation protocol, starting dose of exogenous gonado tropins, or both. AMH level has also demonstrated good predictive value for a number of in-vitro fertilization (IVF) outcomes.

\section{Anti-MüLlerian hormone level advantages}

a. Good predictive value for the number of oocytes retrieved and stimulation response.

b. May help guide protocol and other treatment decisions.

c. Well-characterized across adolescent and reproductive ages.

d. Can be performed at any point during a cycle (lowintracyclevariability). AMH remains relatively stable through- out the menstrual cycle, with the fluctuations reported in some studies appearing to be of small amplitude

e. Good inter-cycle consistency.

f. Good inter-operator and inter-centre consistency.

g. Relatively low cost (depending upon the specific antiMüllerian hormone assay) 


\section{Anti-MüLlerian hormone level disadvantages}

Problems of AMH measurements: Yet from a practical stand point, in addition to cost, problems related to AMH measurement shaver aised doubts about their clinical sound ness. These problems essentially are attributed, on the one hand, to anun coordinated development of AMH assays, which displayed different callibration and standards and, on the other hand, to the compulsory operator- and technique-dependent manipulations. Recently, to over come these limitations and to improve quality of AMH measurements, fully automated AMH assays (Access AMH [Beckman Coulter] and Elecsys AMH [Roche Diagnostics International]) have been developed and commercialized.
Associated or not to ultra sonographic counting of antral follicles, serum antimullerian hormone (AMH) measurements have become the reference in the clinical appraisal of the ovarian follicular status. The ideal ovarian reserve test should be reproducible, with limit edinter- and intra-cycle variability, and demonstrate high specificity to minimize the risk for incorrectly. Categorizing women as having decreased ovarian reserve. No measure of ovarian reserve is perfect; however, AMH level have good predictive value.

Assessmen to serum AMH should only be discussed for patients at risk of ovarian failure.

Your next submission with Juniper Publishers will reach you the below assets

- Quality Editorial service

- Swift Peer Review

- Reprints availability

- E-prints Service

- Manuscript Podcast for convenient understanding

- Global attainment for your research

- Manuscript accessibility in different formats

( Pdf, E-pub, Full Text, Audio)

- Unceasing customer service

Track the below URL for one-step submission https://juniperpublishers.com/online-submission.php 